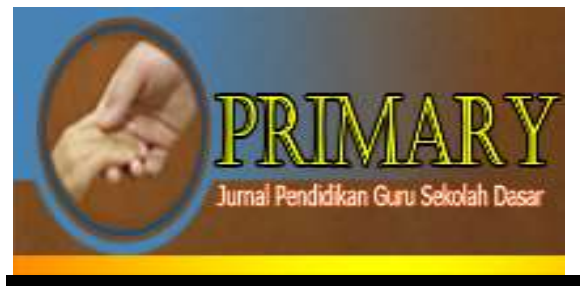

\author{
PRIMARY: JURNAL PENDIDIKAN GURU SEKOLAH DASAR \\ VOLUME 10 NOMOR 5 OKTOBER 2021 \\ ISSN : 2303-1514 | E-ISSN : 2598-5949 \\ DOI : http://dx.doi.org/10.33578/jpfkip.v10i5.8278 \\ https://primary.ejournal.unri.ac.id/index.php/JPFKIP
}

\title{
DEVELOPING 3-D BASED RUBERGY (RUMAH SUMBER ENERGI) LEARNING MEDIA
}

\author{
Alifia Munaamah ${ }^{1}$, Encep Andriana ${ }^{2}$, A. Syachruroji ${ }^{3}$ \\ ${ }^{1,2,3}$ Universitas Sultan Ageng Tirtayasa, Banten, Indonesia

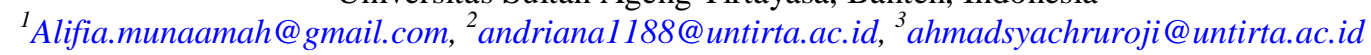
PENGEMBANGAN MEDIA PEMBELAJARAN RUBERGI (RUMAH SUMBER ENERGI) BERBASIS MEDIA 3 DIMENSI

\begin{tabular}{|c|c|}
\hline ARTICLE HISTORY & ABSTRACT \\
\hline $\begin{array}{l}\text { Submitted: } \\
04 \text { September } 2021 \\
04^{\text {th }} \text { September } 2021\end{array}$ & $\begin{array}{l}\text { Abstract: This study aimed to determine how to develop Rubergi (Rumah Sumber Energi) } \\
\text { Learning Media based on 3-D media at grade IV, to determine the feasibility of Rubergi } \\
\text { learning media, and to determine students' responses to rubergi learning media. This research } \\
\text { was conducted at SDN Toyomerto 2, which involved } 33 \text { grade IV students. } 13 \text { students were on } \\
\text { a limited trial. This type of research utilized the Trianto development model. This development } \\
\text { consisted of the Definition Stage (Define), the Design Stage (Design), and the Development } \\
\text { Stage (Develop). However, the research was limited to the development stage (Develop), which } \\
\text { was only up to the final product stage. The instruments used were in the form of a } \\
\text { questionnaire sheet for media validation by the lecturer and a students' response questionnaire } \\
\text { sheet. Based on the data analysis, it was concluded that the feasibility of Rubergi learning } \\
\text { media was in very feasible category with a percentage of } 87.14 \% \text { from two media experts, in } \\
\text { very feasible category with a percentage of } 81.73 \% \text { from two material experts, and in very, } \\
\text { feasible category with a percentage of } 84.5 \% \text { from two education experts. The students } \\
\text { responses to Rubergi learning media in a trial with } 13 \text { respondents were } 85.72 \% \text { in the very } \\
\text { good category. Based on these results, the final product, Rubergi learning media, was feasible } \\
\text { to be used in the learning activities for grade four elementary school students. }\end{array}$ \\
\hline
\end{tabular}

Accepted:

08 Oktober 2021

08 ${ }^{\text {th }}$ October 2021

Keywords: rubergi media, 3 dimensional media

\begin{abstract}
Abstrak: Penelitian ini bertujuan untuk mengetahui cara mengembangkan Media Pembelajaran Rubergi (Rumah Sumber Energi) berbasis media 3 dimensi di kelas IV, untuk mengetahui kelayakan media pembelajaran rubergi yang dikembangkan, dan untuk mengetahui respon siswa terhadap media pembelajaran rubergi. Penelitian ini dilakukan di SDN Toyomerto 2 dengan subjek penelitian siswa kelas IV sejumlah 33 orang dengan rincian 13 orang pada uji coba terbatas. Jenis penelitian ini mengacu pada model pengembangan Trianto. Pengembangan ini terdiri dari Tahap Pendefinisian (Define), Tahap Perancangan (Design), dan Tahap Pengembangan (Develop). Akan tetapi penelitiannya dibatasi hanya sampai pada tahap pengembangan (Develop) yakni hanya sampai pada tahapan produk akhir. Instrumen yang digunakan berupa lembar angket untuk validasi media oleh dosen dan lembar angket respon siswa. Berdasarkan analisis data dapat disimpulkan kelayakan media pembelajaran rubergi yang dikembangkan termasuk kategori sangat layak dengan persentase $87.14 \%$ dari dua ahli media, kategori sangat layak dengan persentase $81.73 \%$ dari dua ahli materi, dan kategori sangat layak dengan persentase $84.5 \%$ dari dua ahli pendidikan. Respon siswa terhadap media pembelajaran rubergi pada uji coba dengan 13 responden sebesar $85.72 \%$ dengan kategori sangat baik. Berdasarkan hasil tersebut, produk akhir berupa media pembelajaran rubergi dinyatakan layak untuk digunakan dalam kegiatan pembelajaran siswa kelas IV SD.
\end{abstract}

Kata Kunci: media rubergi, media 3 dimensi

\section{CITATION}

Munaamah, A., Andriana, E., \& Syahcruroji, A. (2021). Developing 3-D Based Rubergi (Rumah Sumber Energi) Learning Media. Primary: Jurnal Pendidikan Guru Sekolah Dasar, 10 (5), 1347-1355. DOI: http://dx.doi.org/10.33578/jpfkip.v10i5.8278. 


\section{PENDAHULUAN}

Pendidikan merupakan hal yang sangat penting dalam kehidupan, baik untuk dirinya sendiri, keluarga, masyarakat, agama, bangsa dan negara. Semakin tinggi pendidikan seseorang maka semakin besar kesempatan untuk meraih kesuksesan. Sebagaimana dinyatakan dalam Undang-undang Nomor 20 Tahun 2003 tentang Sistem Pendidikan Nasional bahwa Pendidikan Nasional bertujuan untuk mengembangkan potensi peserta didik agar menjadi manusia yang beriman dan bertaqwa kepada Tuhan Yang Maha Esa, berakhlak mulia, sehat, berilmu, cakap, kreatif, mandiri, dan menjadi warga Negara yang demokratis serta bertanggungjawab (Trianto, 2012: 3). Pendidikan semestinya mampu menjawab semua persoalan hidup masyarakat, baik ekonomi, sosial, budaya dan karakter. Kemajuan pendidikan tidak cukup diartikan hanya dengan membangun gedung-gedung sekolah standar merata di desa tanpa memperhatikan kelengkapan fasilitas yang mendukung tercapainya misi pendidikan dalam merubah kehidupan yang lebih baik dibandingkan sebelumnya.

Ilmu Pengetahuan Alam (IPA) merupakan mata pelajaran pokok yang ada pada kurikulum pendidikan di Indonesia, salah satunya pada jenjang pendidikan sekolah dasar. IPA juga merupakan mata pelajaran yang mempelajari tentang alam sekitar dengan melakukan pengamatan, eksperimen, penyelidikan, penyusunan teori, dan penyajian gagasan. Dalam pendidikan IPA, siswa diarahkan untuk mencari tahu dan berbuat sehingga siswa dapat memperoleh pemahamannya mengenai alam di sekitarnya dengan lebih mendalam. Melalui mata pelajaran IPA siswa diharapkan dapat mengetahui konsep, prinsip, menumbuhkan cara berpikir ilmiah, memupuk rasa ingin tahu, mengembangkan kemampuan bertanya, dan dapat memecahkan suatu masalah melalui pengamatan, pengumpulan data, diskusi, dan eksperimen. Trianto (2007: 101) menjelaskan kecenderungan pembelajaran IPA pada masa kini adalah peserta didik hanya mempelajari IPA sebagai produk, menghafalkan konsep, teori dan hukum. Keadaan itu diperparah oleh pembelajaran yang berorientasi pada tes/ujian. Akibatnya IPA sebagai proses, sikap dan aplikasi tidak tersentuh dalam pembelajaran.

Pembelajaran merupakan upaya membelajarkan peserta didik untuk belajar. Kegiatan pembelajaran akan melibatkan peserta didik mempelajari sesuatu dengan cara yang efektif dan efisien. Muhaimin dalam Riyanto (2009: 131) menyatakan bahwa pengajaran merupakan aktivitas yang sistematis dan sistemik yang terdiri atas banyak komponen, masing-masing komponen pembelajaran tidak bersifat parsial (terpisah) atau berjalan sendiri-sendiri, tetapi harus berjalan secara teratur, saling bergantung, komplementer, dan berkesinambungan. Untuk itu diperlukan pengolahan pembelajaran yang baik.

Kegiatan pembelajaran IPA harus dilaksanakan dengan memperhatikan tingkat usia anak, yaitu pembelajaran harus mengaitkan materi dengan hal-hal konkrit, artinya materi yang diajarkan harus dapat dipahami dengan mudah oleh siswa. Oleh karena itu dalam melaksanakan kegiatan pembelajaran khususnya mata pelajaran IPA diperlukan sebuah media pembelajaran yang menarik dan kreatif. Dengan adanya media pembelajaran yang menarik dapat membantu siswa memahami pembelajaran IPA dengan mudah, meningkatkan minat belajar siswa, dan pada saat pembelajaran pun tidak membosankan. Pembelajaran yang lebih bermakna akan terwujud dengan adanya bantuan media pembelajaran 3 dimensi agar lebih terlihat nyata atau konkret sehingga dapat membantu mengembangkan potensi yang dimiliki oleh siswa. Media pembelajaran juga dapat memudahkan guru dalam menyampaikan sebuah materi. 
$\begin{array}{cc} & \text { Penggunaan media pembelajaran akan } \\ \text { sangat membantu keefektifan proses }\end{array}$ pembelajaran dan penyampaian pesan dan isi pelajaran pada saat itu. Selain membangkitkan motivasi dan minat siswa, media pembelajaran juga dapat membantu siswa meningkatkan pemahaman, menyajikan data dengan menarik dan terpercaya, memudahkan penafsiran data, dan memadatkan informasi.

Hasil analisis kebutuhan melalui observasi dan wawancara yang dilakukan peneliti terhadap penggunaan media pembelajaran IPA di SDN Toyomerto II diketahui bahwa proses pembelajaran cenderung monoton, guru jarang mengajak siswa untuk berinteraksi secara langsung dengan lingkungan, kurangnya penggunaan media pembelajaran IPA yang tepat dan sesuai serta dapat melibatkan siswa dalam penggunaannya, pada saat proses pembelajaran IPA khususnya materi sumber energi guru belum pernah menggunakan media pembelajaran 3 dimensi, serta kurangnya minat siswa dalam pembelajaran.

Selama ini di SD pelajaran IPA disampaikan melalui metode ceramah dan diskusi saja, sehingga banyak siswa yang kurang memahami materi yang diajarkan oleh guru. Pada hal lain guru masih berpandangan pada paradigma lama yaitu tugas seorang guru adalah mengajarkan pengetahuan dengan cara dihafalkan oleh siswa, Sudibyo (2011: 4). Pembelajaran masih berfokus pada guru sebagai sumber utama pengetahuan. Selain itu ceramah dijadikan pilihan utama metode mengajar. Dapat disimpulkan dari hasil analisis kebutuhan bahwa sangat dibutuhkan sebuah media pembelajaran IPA yang berguna sebagai alat yang dapat menyalurkan informasi, pengetahuan dan dapat menarik perhatian siswa agar lebih termotivasi dalam belajar serta meningkatkan konsentrasi belajar peserta didik.

Terkait pemaparan ahli di atas, maka penulis mengembangkan media pembelajaran Rubergi berbasis 3 dimensi. Penggunaan media ini bertujuan membantu siswa untuk mengetahui macam-macam sumber energi yang ada dalam keidupan sehari-hari. Siswa dapat melihat gambaran sumber energi baik energi panas, cahaya, dan listrik dengan menggunakan benda konkret seperti, lampu, setrika, batu baterai, dan lain-lain. Media pembelajaran Rubergi ini mudah digunakan oleh guru dan bersifat tahan lama, dapat membuat suasana belajar menjadi menyenangkan, dengan menggunakan media ini belajar dapat difokuskan pada bagianbagian yang penting saja, dan media ini dapat memotivasi siswa dalam mengikuti materi pembelajaran. Selain itu, siswa tidak bosan dengan pembelajaran di kelas, siswa memperoleh pengalaman yang konkrit, medianya pun mudah dibuat dan bahannya mudah diperoleh di lingkungan sekitar, serta dapat memberikan gambaran visual tentang sumber energi dalam kehidupan sehari-hari.

Berdasarkan uraian di atas, peneliti ingin mengembangkan sebuah media pembelajaran IPA untuk kelas IV Sekolah Dasar, media pembelajaran IPA tersebut adalah Rubergi (Rumah Sumber Energi).

Adapun tujuan yang ingin dicapai dan telah dirumuskan dalam penelitian ini, yakni untuk:

1. Mengetahui kelayakan Media Pembelajaran Rubergi (Rumah Sumber Energi) berbasis 3 dimensi bagi siswa kelas IV pada mata pelajaran IPA

2. Mengetahui respon siswa kelas IV terhadap media pembelajaran Rubergi (Rumah Sumber Energi) berbasis media 3 dimensi pada mata pelajaran IPA

\section{KAJIAN TEORI}

Menurut Undang-Undang Republik Indonesia Nomor 18 Tahun 2012 dalam Setyosari (2013: 222-223), Pengembangan adalah kegiatan ilmu pengetahuan dan teknologi yang bertujuan memanfaatkan kaidah dan teori ilmu pengetahuan yang telah terbukti kebenarannya untuk meningkatkan fungsi, manfaat, dan aplikasi ilmu pengetahuan dan teknologi yang telah ada atau 
menghasilkan teknologi baru. Pengembangan adalah suatu proses yang dipakai untuk mengembangkan dan memvalidasi produk pendidikan. Penelitian ini mengikuti suatu langkah-langkah secara siklus. Langkah penelitian atau proses pengembangan ini terdiri atas kajian tentang temuan penelitian produk yang akan dikembangkan, mengembangkan produk berdasarkan temuan-temuan tersebut, melakukan uji coba lapangan sesuai dengan latar di mana produk tersebut akan dipakai, dan melakukan revisi terhadap hasil uji lapangan.

Dari pendapat ahli di atas, dapat disimpulkan bahwa pengembangan merupakan suatu usaha yang dilakukan secara sadar, terencana, terarah untuk membuat atau memperbaiki, sehingga menjadi produk yang semakin bermanfaat untuk meningkatkan kualitas sebagai upaya untuk menciptakan mutu yang lebih baik.

\section{Media Pembelajaran}

Media pembelajaran didefinisikan oleh Heinich dalam Daryanto (2010: 4) kata media merupakan bentuk jamak dari kata medium. Medium dapat didefinisikan sebagai perantara atau pengantar terjadinya komunikasi dari pengirim menuju penerima. Media merupakan salah satu komponen komunikasi, yaitu sebagai pembawa pesan dari komunikator menuju komunikan. Sedangkan menurut Sukiman (2012: 29) mengungkapkan media pembelajaran adalah segala sesuatu yang dapat digunakan untuk menyalurkan pesan dari penerima sehingga dapat merangsang pikiran, perasaan, perhatian dan minat serta kemauan siswa sehingga proses belajar terjadi untuk mencapai tujuan pembelajaran secara efektif.

Dari beberapa pengertian media pembelajaran di atas dapat disimpulkan bahwa media pembelajaran merupakan suatu alat yang dipakai untuk mencapai tujuan pendidikan yang dapat membantu proses belajar mengajar dan berfungsi untuk memperjelas makna pesan yang disampaikan oleh guru sehingga mampu merangsang pikiran, perasaan, perhatian, dan minat serta kemauan siswa agar tujuan pembelajaran tercapai secara efektif.

\section{Media Diorama}

Menurut Sudjana dan Rivai (2010: 170) diorama adalah pemandangan sebuah dimensi mini, bertujuan untuk menggambarkan pemandangan sebenarnya. Diorama biasanya menggambarkan bentuk-bentuk sosok atau objek-objek ditempatkan di pentas yang berlatar belakang lukisan yang disesuaikan dengan penyajian. Diorama sebagai media pengajaran terutama berguna untuk mata pelajaran ilmu bumi, ilmu hayat, sejarah bahkan dapat diusahakan pula untuk berbagai macam mata pelajaran.

Dari pernyataan para ahli di atas, maka dapat disimpulkan bahwa media diorama adalah media tiga dimensi yang berisi tiruan dari objek-objek yang berukuran kecil dan bertujuan untuk menggambarkan keadaan atau suasana seperti aslinya yang sulit disajikan di dalam kelas.

\section{Ilmu Pengetahuan Alam (IPA)}

Menurut De Vito, et al dalam Samatowa (2006: 146) pembelajaran IPA yang baik harus mengaitkan IPA dengan kehidupan sehari-hari siswa. Siswa diberi kesempatan untuk mengajukan pertanyaan, membangkitkan ide-ide siswa, membangun rasa ingin tahu tentang segala sesuatu yang ada di lingkungannya, membangun keterampilan (skill) yang diperlukan, dan menimbulkan kesadaran siswa bahwa belajar IPA menjadi sangat diperlukan untuk dipelajari.

Dari pendapat beberapa ahli di atas, dapat disimpulkan pembelajaran IPA di Sekolah Dasar dapat melatih dan memberikan kesempatan kepada siswa untuk mengembangkan keterampilan-keterampilan proses dan dapat melatih siswa untuk dapat berpikir serta bertindak secara rasional dan kritis terhadap persoalan yang bersifat ilmiah yang ada di lingkungannya. Keterampilanketerampilan yang diberikan kepada siswa 
sebisa mungkin disesuaikan dengan tingkat perkembangan usia dan karakteristik siswa Sekolah Dasar, sehingga siswa dapat menerapkannya dalam kehidupannya seharihari.

\section{METODE PENELITIAN}

Dalam penelitian ini metode yang digunakan yaitu metode Research and Development (R\&D) atau disebut juga dengan penelitian dan pengembangan. Rancangan penelitian pengembangan ini bertujuan untuk menghasilkan suatu produk yaitu sebuah media pembelajaran berbasis visual dengan memanfaatkan media pembelajaran Rubergi yang bisa digunakan dalam proses belajar mengajar yang menyenangkan di sekolah. Menurut Sugiyono (2015: 407) metode penelitian dan pengembangan atau dalam bahasa inggrisnya Research and Development adalah metode penelitian yang digunakan untuk menghasilkan produk tertentu, dan menguji keefektifan produk tersebut. Produk yang dikembangkan bertujuan untuk mengatasi permasalahan-permasalahan di dalam kelas maupun di luar kelas.

Penelitian ini dilakukan di SDN Toyomerto 2, Kab. Serang, Banten. Adapun alasan peneliti memilih sekolah ini dikarenakan SDN Toyomerto 2 merupakan sekolah percontohan kurikulum 2013, sehingga memudahkan peneliti dalam mendapatkan informasi yang diperlukan. Penelitian ini dilakukan pada semester ganjil tahun ajaran
2020/2021 dengan jumlah siswa sebanyak 13 orang.

Populasi yang peneliti gunakan dalam penelitian ini adalah seluruh siswa di SDN Toyomerto 2, Kabupaten Serang Tahun Pelajaran 2020/2021. Sedangkan sampel pada penelitian ini adalah siswa kelas IV SDN Toyomerto 2 Kabupaten Serang Tahun Pelajaran 2020/2021 dengan jumlah siswa sebanyak 13 orang.

Pada langkah model penelitian pengembangan ini mengikuti langkah model pengembangan yang dikemukakan oleh Trianto (2012: 94) yaitu, tahap pendefinisian (define), tahap perancangan (design), tahap pengembangan (develop) dan penyebaran (disseminate). Dalam penelitian ini peneliti hanya melakukan sampai 3-D atau dibatasi sampai tahap pengembangan (develop).

Instrumen yang digunakan dalam penelitian ini adalah angket. Angket digunakan untuk mendapatkan data tentang kelayakan produk media pembelajaran rubergi. Ada empat macam angket yang digunakan dalam penelitian ini yaitu, (1) angket validasi ahli media, (2) angket validasi ahli materi, (3) angket validasi ahli materi, dan (4) angket respons siswa.

Adapun kisi-kisi angket $\begin{array}{r}\text { yang } \\ \text { digunakan dalam penelitian }\end{array}$
pengembangan media pembelajaran
rubergi
antara lain sebagai berikut:
1. Angket Validasi Ahli Media

Tabel 1. Kisi-kisi Instrumen Uji Ahli Media

\begin{tabular}{lllcc}
\hline No. & \multicolumn{1}{c}{ Kriteria } & \multicolumn{1}{c}{ Indikator } & No. Pernyataan & $\begin{array}{c}\text { Jumlah Butir } \\
\text { Soal }\end{array}$ \\
\hline \multirow{2}{*}{$\begin{array}{l}\text { Aspek Kelayakan } \\
\text { Kegrafikan }\end{array}$} & A. Ukuran media & 1,2 & 2 \\
& B. Ilustrasi isi & $3,4,5,6,7,8$ & 6 \\
& C. Kualitas dan tampilan media & $9,10,11,12,13$, & 6 \\
& & Jumlah & 14 & 14
\end{tabular}

BSNP (Purwono, 2008) yang telah termodifikasi 


\section{PRIMARY: JURNAL PENDIDIKAN GURU SEKOLAH DASAR \\ VOLUME 10 NOMOR 5 OKTOBER 2021 \\ ISSN : 2303-1514 | E-ISSN : 2598-5949 \\ DOI : http://dx.doi.org/10.33578/jpfkip.v10i5.8278 \\ https://primary.ejournal.unri.ac.id/index.php/JPFKIP}

Tabel 2. Kisi-kisi Instrumen Uji Ahli Materi

\begin{tabular}{|c|c|c|c|c|}
\hline No. & Kriteria & Indikator & No. Pernyataan & $\begin{array}{c}\text { Jumlah } \\
\text { Butir Soal }\end{array}$ \\
\hline \multirow{4}{*}{1.} & \multirow{4}{*}{ Aspek Kelayakan Isi } & A. Kesesuaian Kurikulum & $1,2,3$ & 3 \\
\hline & & B. Keakuratan Materi & $4,5,6$ & 3 \\
\hline & & C. Kemutakhiran Materi & $7,8,9$ & 3 \\
\hline & & D. Mendorong Keingintahuan & $10,11,12$ & 3 \\
\hline \multirow{3}{*}{2.} & \multirow{3}{*}{$\begin{array}{l}\text { Aspek Kelayakan } \\
\text { Penyajian }\end{array}$} & Teknik Penyajian & $13,14,15$ & 3 \\
\hline & & Penyajian Pembelajaran & $16,17,18$ & 3 \\
\hline & & Hakikat Kontekstual & $19,20,21$ & 3 \\
\hline \multirow[t]{2}{*}{3.} & $\begin{array}{l}\text { Aspek Penilaian } \\
\text { Kontekstual }\end{array}$ & Komponen kontekstual & $22,23,24$ & 3 \\
\hline & & Jumlah & & 24 \\
\hline
\end{tabular}

3. Angket Validasi Ahli Pendidikan

Tabel 3. Kisi-kisi Instrumen Uji Ahli Pendidikan

\begin{tabular}{|c|c|c|c|c|}
\hline $\begin{array}{c}\text { No } \\
\text {. }\end{array}$ & Kriteria & Indikator & $\begin{array}{c}\text { No. } \\
\text { Pernyataan }\end{array}$ & $\begin{array}{c}\text { Jumlah Butir } \\
\text { Soal }\end{array}$ \\
\hline \multirow{6}{*}{1.} & I. .Tujuan & A. Kejelasan tujuan pembelajaran & 1,2 & 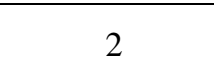 \\
\hline & \multirow{4}{*}{ II. Aktivitas Siswa } & $\begin{array}{l}\text { B. Kesesuaian isi media dengan } \\
\text { Kompetensi Dasar (KD) dan } \\
\text { indikator pembelajaran }\end{array}$ & 3,4 & 2 \\
\hline & & C. Ketepatan cakupan materi & 5,6 & 2 \\
\hline & & $\begin{array}{l}\text { D. Kebenaran konsep materi melalui } \\
\text { aktivitas siswa }\end{array}$ & 7,8 & 2 \\
\hline & & $\begin{array}{l}\text { E. Kesesuaian media dengan materi } \\
\text { dan kehidupan sehari-hari }\end{array}$ & 9,10 & 2 \\
\hline & III. Penyajian & $\begin{array}{l}\text { F. Kemampuan dalam memberikan } \\
\text { interaksi langsung antara pengguna } \\
\text { dan materi pembelajaran }\end{array}$ & 11,12 & 2 \\
\hline
\end{tabular}

Kualitas Media Pembelajaran

\begin{tabular}{clcc}
\multirow{2}{*}{ 2. TV. Tampilan } & A. Pemilihan objek & 13,14 & 2 \\
& B. Pemilihan background & 15,16 & 2 \\
V. Pengaplikasian & C. Pemilihan warna & 17,18 & 2 \\
& D. Kualitas media & 19,20 & 2 \\
& & & \\
& & & \\
\end{tabular}

4. Angket Respons Siswa

(Modifikasi Akbar, 2013: 122) 
Tabel 4. Kisi-kisi Instrumen Respons Siswa

\begin{tabular}{|c|c|c|c|c|c|}
\hline \multirow{2}{*}{\multicolumn{2}{|c|}{ Aspek }} & \multirow{2}{*}{ Indikator } & \multicolumn{2}{|c|}{ Pernyataan } & \multirow{2}{*}{$\begin{array}{l}\text { Jumlah } \\
\text { Butir Soal }\end{array}$} \\
\hline & & & Positif & Negatif & \\
\hline \multirow{3}{*}{ I. } & \multirow{3}{*}{$\begin{array}{l}\text { Tampila } \\
\mathrm{n}\end{array}$} & A. Kemenarikan Objek & 1 & 2 & 2 \\
\hline & & B. Kemenarikan komposisi warna & 3 & 4 & 2 \\
\hline & & C. Kemenarikan ilustrasi & 5 & 6 & 2 \\
\hline \multirow[t]{4}{*}{ II. } & Penyaji & A. Penyajian materi & 7 & 8 & 2 \\
\hline & & B. Kemudahan memahami materi & 9 & 10 & 2 \\
\hline & Materi & C. Kesesuaian objek dengan materi & 11 & 12 & 2 \\
\hline & & A. Kemudahan belajar & 13 & 14 & 2 \\
\hline \multirow[t]{3}{*}{ III. } & Manfaat & B. Ketertarikan menggunakan media & 15 & 16 & 2 \\
\hline & & C. Peningkatan minat belajar & 17 & 18 & 2 \\
\hline & & Jumlah & & & 18 \\
\hline
\end{tabular}

BSNP (Purwono, 2008) yang telah termodifikasi

\section{HASIL DAN PEMBAHASAN}

Hasil penelitian ini diperoleh setelah peneliti tahap uji validasi terhadap tim ahli dan uji coba terbatas terhadap siswa. Berikut adalah uraian masing-masing dari hasil penelitian ini:

Berdasarkan tabel analisis data penelitian ahli media, didapatkan hasil validasi dari ahli media I sebesar $88.57 \%$ dan hasil validasi ahli media II sebesar $85.71 \%$. Dengan demikian hasil rata-rata persentase akhir validasi ahli media yaitu sebesar $87.14 \%$ dengan kategori kriteria interpretasi "Sangat Layak".

Berdasarkan tabel data penilaian di atas, didapatkan hasil validasi dari ahli materi I sebesar $82.60 \%$ dan hasil validasi ahli materi II sebesar $80.86 \%$. Dengan demikian hasil ratarata persentase akhir validasi ahli materi sebesar $81.73 \%$ dengan kategori kriteria interpretasi "Sangat Layak".

Berdasarkan tabel data penilaian di atas, didapatkan hasil validasi dari ahli pendidikan I sebesar $83 \%$ dan hasil validasi ahli pendidikan II sebesar $86 \%$. Dengan demikian hasil rata-rata persentase akhir validasi ahli pendidikan sebesar $84.5 \%$ dengan kategori kriteria interpretasi "Sangat Layak".

Berdasarkan tabel data hasil respon siswa terhadap media pembelajaran rubergi berbasis media 3 dimensi, maka diperoleh nilai akhir sebesar $85.72 \%$ yang apabila diinterpretasikan telah mencapai kategori "Sangat Baik".

\section{Pembahasan}

Produk yang dikembangkan dalam penelitian ini adalah media pembelajaran rubergi berbasis media tiga dimensi sebagai media pemeblajaran IPA materi sumber energi untuk Sekolah Dasar Kelas IV. Berdasarkan hasil analisis kebutuhan, perlu adanya media tiga dimensi yang dikembangkan karena kurangnya variasi guru dalam menggunakan media pada materi sumber energi yang memiliki keterbatasan ruang dan waktu.

Media pembelajaran tiga dimensi ini merupakan penelitian dan pengembangan untuk mempermudah guru dalam menyampaikan materi pembelajaran. Dengan adanya media pembelajaran ini, diharapkan siswa mendapat pengalaman belajar yang bersifat konkret dan realistis, mengatasi keterbatasan siswa dalam berinteraksi langsung dengan lingkungan, membangkitkan minat dan motivasi belajar siswa dan memudahkan siswa dalam melakukan kegiatan pengamatan. Rusman (2013: 162) mengungkapkan bahwa media pembelajaran merupakan alat yang memungkinkan siswa untuk mengerti dan memahami sesuatu dengan mudah untuk mengingatnya dalam waktu yang 
lama dibandingkan dengan penyampaian materi pelajaran dengan cara tatap muka dan ceramah tanpa alat bantu atau media pembelajaran.

Penelitian difokuskan pada pengembangan media pembelajaran rubergi berbasis media tiga dimensi dengan menggunakan model pengembangan 3-D yang dikemukakan Trianto (2012: 94) yaitu: tahap pendefinisian (Define) yang terdiri dari analisis kurikulum, analisis materi, dan analisis kebutuhan; tahap perancangan (Design) yang terdiri dari pengumpulan informasi dan desain produk; dan tahap pengembangan (Develop) yang terdiri dari validasi desain, revisi produk, dan uji coba produk (uji coba terbatas).

Media pembelajaran Rubergi dikemas dalam bentuk 3 dimensi di mana dapat menunjukkan miniatur rumah beserta sumber energi seperti yang terjadi dalam kehidupan sehari-hari karena media rubergi ini untuk memvisualisasikan materi yang mengandung unsur ukuran yang tidak dapat disajikan di dalam kelas. Media pembelajaran rubergi disajikan lengkap dengan rumah beserta peralatan yang berhubungan dengan sumber energi. Kemudian siswa akan melakukan kegiatan pengamatan pada materi sumber energi lalu siswa akan membuktikan terjadinya perubahan energi yang ada pada media tersebut sesuai dengan pernyataan Sudjana dan Rivai (2011: 2) tentang manfaat media pembelajaran salah satunya ialah siswa lebih banyak melakukan kegiatan belajar, tidak hanya mendengarkan uraian guru, tetapi juga aktivitas lain seperti mengamati, melakukan, dan mendemonstrasikan.

Media Pembelajaran Rubergi yang dikembangkan peneliti tentu tidak mudah untuk mendapatkan kategori "Sangat Baik". Peneliti harus melalui serangkaian proses yang cukup panjang dan mengeluarkan biaya yang tidak sedikit. Proses pembuatan media ini juga memerlukan kreativitas dan kesabaran mulai dari tahap mendesain hingga membuatnya menjadi bentuk fisik.
Dengan demikian, berdasarkan hasil dari respon siswa media pembelajaran rubergi ini dapat menarik minat dan perhatian belajar karena siswa terlihat lebih aktif, karena pembelajaran dilakukan lebih bervariasi dengan adanya media pembelajaran rubergi sehingga siswa tidak bosan dan tidak hanya menggunakan komunikasi verbal saja, siswa juga terlihat antusias terhadap pembelajaran karena media pembelajaran rubergi ini merupakan hal baru bagi mereka sehingga menimbulkan rangsangan terhadap siswa agar memiliki kemauan untuk belajar dan menggali kemampuan dan potensi yang dimilikinya supaya tujuan pembelajaran dapat tercapai secara maksimal.

\section{SIMPULAN DAN REKOMENDASI}

Berdasarkan hasil penelitian dan pembahasan yang telah dijabarkan oleh peneliti, maka dapat disimpulkan bahwa:

1. Kelayakan media pembelajaran rubergi didapatkan dari hasil penilaian ahli media, ahli materi, dan ahli pendidikan. Hasil penilaian dari ahli media memperoleh ratarata skor persentase sebesar $87.14 \%$ yang masuk pada kriteria "Sangat Layak". Hasil penilaian dari ahli materi memperoleh rata-rata skor persentase nilai akhir sebesar $81.73 \%$ yang masuk pada kriteria "Sangat Layak". Sedangkan hasil dari ahli pendidikan memperoleh rata-rata skor persentase nilai akhir sebesar $84.5 \%$ yang masuk pada kriteria "Sangat Layak". Jika dihitung pencapaian hasil penilaian validasi ahli, maka dapat dikatakan bahwa media pembelajaran rubergi ini mendapatkan nilai uji kelayakan dengan perolehan angka rata-rata sebesar $84.45 \%$ melalui uji validasi ahli, sehingga mendapatkan kategori "Sangat Layak".

2. Hasil respon siswa pada pengembangan media pembelajaran rubergi memperoleh rata-rata skor sebesar $85.72 \%$ dengan kategori "Sangat Baik".

Adapun beberapa saran yang diajukan berdasarkan hasil penelitian ini, diantaranya 
yaitu: 1) penelitian pengembangan media pembelajaran rubergi ini hanya sebatas pada materi sumber energi saja. Oleh karena itu, disarankan kepada peneliti selanjutnya agar dapat mengembangkan media pembelajaran rubergi ini pada materi atau mata pelajaran lainnya, 2) produk yang dihasilkan dari penelitian dan pengembangan ini adalah berupa media pemeblajaran dalam bentuk 3 dimensi, maka yang perlu diperhatikan dalam pembuatannya tidak boleh melupakan karakteristik media itu sendiri, karakteristik siswa, sifat pesan, dan prosedur penggunaannya. Produk pengembangan media pembelajaran rubergi ini dapat menjadi pilihan perangkat pembelajaran untuk menunjang proses pembelajaran pada materi sumber energi pada kelas IV untuk mempermudah guru dalam menyampaikan materi pemeblajaran dan membantu siswa untuk mendapat pengalaman belajar yang bersifat konkret dan realistis, membangkitkan minat dan motivasi belajar siswa dan memudahkan siswa dalam melakukan kegiatan pengamatan.

\section{DAFTAR PUSTAKA}

Akbar, S. (2013). Instrumen Perangkat Pembelajaran. Bandung: PT. Remaja Rosdakarya.

Daryanto. (2010). Media Pembelajaran. Yogyakarta: Gaya Media.

Purwono, U. (2008). Standar Penilaian Buku Pelajaran.

http://web.iaincirebon.ac.id/ebook/indr ya/jurnal\%20internasional/textbook/B ahan. Diakses pada tanggal 15 Desember 2019

Riyanto, Y. (2009). Paradigma Baru Pembelajaran. Jakarta: Kencana.
Rusman, D. K., \& Riyana, C. (2013). Pembelajaran Berbasis Teknologi Informasi dan Komunikasi Mengembangkan Profesionalitas Guru. Jakarta: Rajawali Pers.

Samatowa, U. (2006). Bagaimana Membelajarkan IPA di Sekolah Dasar. Jakarta: Direktorat Pendidikan Nasional.

Setyosari, P. (2013). Metode Penelitian Pendidikan dan Pengembangan. Jakarta: Kencana.

Sudibyo. (2011). Peningkatan Keaktifan Siswa dan Hasil Belajar Melalui Media Permainan Umbul pada Mata Pelajaran IPA Pokok Bahasan Sumber Energi Kelas II SDN Sidomulyo 03 Kecamatan Batu Kota Batu. Skripsi. Malang: Universitas Muhammadiyah Malang.

Sudjana, N \& Ahmad Rivai. (2010). Media Pengajaran. Bandung: Sinar Baru Algensindo.

Sudjana. (2011). Media Pengajaran. Bandung: Sinar Baru Algensindo.

Sugiyono. (2015). Metode Penelitian Pendidikan (Pendekatan Kuantitatif, Kualitatif, dan $R \& D)$. Bandung: Alfabeta.

Sukiman. (2012). Pengembangan Media Pembelajaran. Yogyakarta: Pustaka Insan.

Trianto. (2007). Model Pembelajaran Terpadu. Jakarta: Prestasi Pustaka

Trianto. (2012). Model Pembelajaran Terpadu. Jakarta: Bumi Aksara. 